This item was submitted to Loughborough's Research Repository by the author.

Items in Figshare are protected by copyright, with all rights reserved, unless otherwise indicated.

\title{
Inorganic profiles of chemical phosphorus removal sludge
}

PLEASE CITE THE PUBLISHED VERSION

http://dx.doi.org/10.1680/wama.2010.163.2.65

PUBLISHER

ICE Publishing

VERSION

VoR (Version of Record)

LICENCE

CC BY-NC-ND 4.0

REPOSITORY RECORD

Carliell-Marquet, Cynthia, Jennifer Smith, loannis Oikonomidis, and Andrew D. Wheatley. 2019. "Inorganic Profiles of Chemical Phosphorus Removal Sludge". figshare. https://hdl.handle.net/2134/15248. 
This item was submitted to Loughborough's Institutional Repository (https://dspace.lboro.ac.uk/) by the author and is made available under the following Creative Commons Licence conditions.

\section{creative
commons}

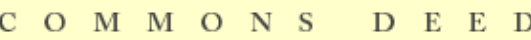

Attribution-NonCommercial-NoDerivs 2.5

You are free:

- to copy, distribute, display, and perform the work

Under the following conditions:

Attribution. You must attribute the work in the manner specified b the author or licensor.

Noncommercial. You may not use this work for commercial purposes.

No Derivative Works. You may not alter, transform, or build upon this work.

- For any reuse or distribution, you must make clear to others the license terms of this work.

- Any of these conditions can be waived if you get permission from the copyright holder.

Your fair use and other rights are in no way affected by the above.

This is a human-readable summary of the Leqal Code (the full license).

\section{Disclaimer 만}

For the full text of this licence, please go to: http://creativecommons.org/licenses/by-nc-nd/2.5/ 


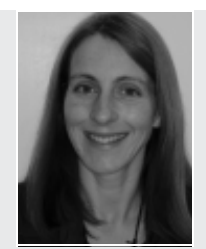

Cynthia Carliell-Marquet Lecturer, Department of Engineering, University of Birmingham, UK
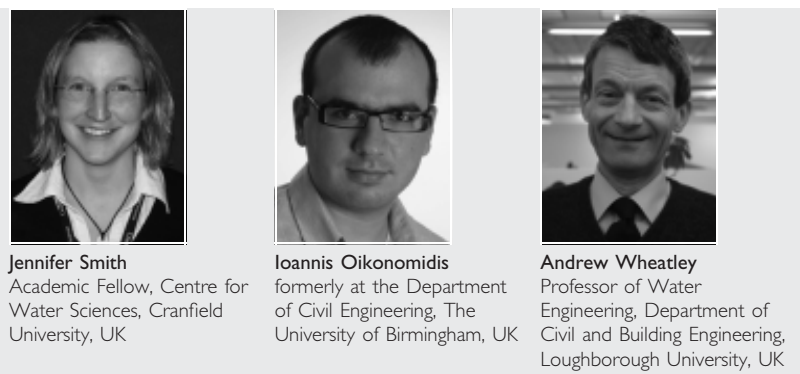

\section{Inorganic profiles of chemical phosphorus removal sludge}

C. Carliell-Marquet PhD, J. Smith PhD, I. Oikonomidis PhD and A. Wheatley PhD

Iron dosing is commonly used to remove phosphorus from wastewater but little is known about how this changes the distribution of iron, phosphorus, calcium, magnesium and trace metals in activated and digested sludge. This research compared the inorganic profiles of sludge from full-scale processes (activated sludge and anaerobic digestion) with and without iron dosing, with the aim of identifying changes in inorganic distribution resulting from iron dosing. Sludge phosphorus and metals were fractionated using sequential chemical extraction. Bioavailable iron was lower in iron-dosed activated sludge, as was bioavailable phosphorus $(6.5 \mathrm{~g} / \mathrm{kg}$ compared with $1.8 \mathrm{~g} / \mathrm{kg}$ ), with most of the iron and phosphorus bound as iron-hydroxy-phosphates. Similar results were found for anaerobically digested sludge after iron dosing; iron and phosphorus in the sludge increased by 4 and I.35 times, respectively, but bioavailability was decreased. The ratio of chemical oxygen demand to bioavailable phosphorus in the digester was 840 : I after iron dosing. By contrast, calcium, magnesium, copper and zinc were increasingly bioavailable in the digester after iron dosing. The reported changes were linked to the iron content of the sludge; hence the level of iron dosing is key to minimising changes in sludge inorganic profiles.

\section{INTRODUCTION}

The final effluent from sewage treatment works (STW) is a significant point source of phosphorus (P) into the environment. The EU urban wastewater treatment directive (UWWTD 91/271/EEC) requires all STW with a population equivalent greater than 10000 to meet discharge consents of 1-2 $\mathrm{mg} \mathrm{PO}_{4}{ }^{3-}-\mathrm{P} / \mathrm{l}$ if discharging into designated nutrientsensitive waters. Nature conservation legislation can also be used to impose phosphorus consents when STW discharge into protected areas, such as special areas of conservation (EU Habitats Directive 92/43/EEC), regardless of the size of the STW. In the UK it is estimated that, by 2010, 298 STW will remove phosphorus for the UWWTD and 328 to 342 for nature conservation (Mounsey, 2004). The vast majority will use chemical phosphorus removal (CPR).

Chemical phosphorus removal processes are based on the addition of a metal salt to wastewater, causing precipitation of an insoluble phosphate, which is settled out with the wastewater sludge (Yeoman et al., 1988). Currently in the UK, iron (Fe) salts are those most commonly used for CPR. The iron salts are usually derived from waste products (Kirk et al., 1987).

Iron-dosing can be done at one or a combination of stages in sewage treatment: $(a)$ pre-precipitation, in which ferric salts are added to raw sewage; (b) co-precipitation, in which ferrous salts are commonly dosed into the aeration basin of the activated sludge (AS) process, Fe(II) being oxidised to Fe(III) prior to orthophosphate $\left(\mathrm{PO}_{4}{ }^{3-}\right)$ precipitation; and (c) postprecipitation, in which chemicals are added before or after secondary settlement.

The mass of iron required to precipitate 1 mole of phosphorus can be calculated theoretically

$$
\mathrm{Fe}^{3+}+\mathrm{PO}_{4}^{3-} \leftrightarrow \mathrm{FePO}_{4(\mathrm{~s})}
$$

In reality, however, the relationship between the metal salt dose and the phosphorus to be removed is not stoichiometric (Fytianos et al., 1998; Jenkins et al., 1971). The extent of precipitation, and the products formed, is a function of temperature, metal salt dose, $\mathrm{pH}$ (Singer, 1972; Yeoman et al., 1988), dissolved oxygen and redox potential (Thistleton et al., 2001).

When Fe(III) salts are dosed to wastewater, positively charged polycations are formed, which complex rapidly with $\mathrm{PO}_{4}{ }^{3-}-\mathrm{P}$ and soluble organic anions, thus diverting the normal hydrolysis pathway. Destabilisation of negatively charged colloidal contaminants (such as particulate phosphorus or organic matter), and complexation with anionic sites on the floc surface, occurs with the remaining polycations.

Precipitation proceeds by aggregation of the different subunits, sweep-flocculating the remaining colloidal anionic matter and eventually coating the floc surfaces. Once the amorphous precipitates (Fe(III) hydroxide and $\mathrm{Fe}(\mathrm{III})$-hydroxy-phosphate) have formed, further adsorption of $\mathrm{PO}_{4}{ }^{3-}-\mathrm{P}$ takes place on their surfaces, but at a slower rate. When Fe(II) is used for CPR, it is usually oxidised to $\mathrm{Fe}(\mathrm{III})$ and then follows a similar reaction pathway to that described above. At normal aeration levels (D0 $\approx 1.5 \mathrm{mg} / \mathrm{l}$ ), oxidation takes place rapidly and generates Fe(III) in situ (Nielsen, 1996; Straub et al., 2001) prior to $\mathrm{PO}_{4}{ }^{3-}-\mathrm{P}$ precipitation. 
Iron-dosed CPR sludge will, therefore, contain a mixture of:

(a) Fe(III)-hydroxy-phosphate complexes (general formula $\left.\mathrm{Fe}_{\mathrm{r}} \mathrm{PO}_{4}(\mathrm{OH})_{3 \mathrm{r}-3}\right)$, which act as centres for further precipitation of $\mathrm{Fe}(\mathrm{III})$ hydrolysis products; the stoichiometry of the precipitate formed being a consequence of varying $\mathrm{pH}, \mathrm{PO}_{4}{ }^{3-}-\mathrm{P}$ and iron concentrations (De Haas et al., 2000; Jiang and Graham, 1998; Thistleton et al., 2001, 2002). The proportion of $\mathrm{OH}^{-}$ compared to $\mathrm{PO}_{4}{ }^{3-}$ increases with increasing $\mathrm{pH}$ and iron : phosphorus ratio (Fytianos et al., 1998).

(b) Amorphous $\mathrm{Fe}(\mathrm{III})$ hydroxide precipitates to which $\mathrm{PO}_{4}{ }^{3-}-\mathrm{P}$ ions are adsorbed (He et al., 1996; Jiang and Graham, 1998; Thistleton et al., 2002; Yeoman et al., 1988).

(c) Iron-coagulated organic material.

Other metals are also bound up in CPR sludge through coprecipitation or adsorption of soluble or particulate trace metals to fe(III)-hydroxy-phosphate compounds during CPR. For example, Fe(III) dosing of a primary effluent $(75 \mathrm{mg} / \mathrm{l})$ removed 59\% of the soluble copper from the influent (Edwards et al., 1997). In another study, the use of lime or alum for CPR was found to 'significantly enhance the removal of lead, copper, trivalent chromium and arsenic' (van Fleet et al., 1974). An additional source of metals in CPR sludge arises from contamination of the dosing chemicals. Some ferric coagulants were found to contain up to $4 \mathrm{mg} / \mathrm{l}$ copper and $46-160 \mathrm{mg} / \mathrm{l}$ manganese as contaminants (Edwards et al., 1997).

The total phosphorus content of CPR sludge also increases relative to that of an undosed sludge. For example, total phosphorus increased by 49\% (416-620 mg/l) and 55\% (625$970 \mathrm{mg} / \mathrm{l} \mathrm{P}$ ) in $\mathrm{Fe}(\mathrm{III})$-dosed primary sludge (Edwards et al., 1997; Kirk et al., 1987). Although CPR sludge is phosphorusrich, the quantity of bioavailable phosphorus might be limited (Kindzierski and Hrudey, 1986) as it is locked up in Fe(III)hydroxy-phosphates. Iron dosing has been reported to decrease soluble P concentrations by $91 \%$ from 35 to $3 \mathrm{mg} / 1$ (Malhrota and Parrillo, 1971).

Chemical phosphorus removal can produce three times more sludge (by mass) in comparison to an undosed process (Mainstone et al., 2000), depending on the dosing location (more sludge is generated from pre-precipitation than from coor post-precipitation (Brett et al., 1997) and the chemical dose ( $2: 1$ iron : phosphorus is a common dosing ratio in the UK (Pearce P, Thames Water, personal communication, 2006; Smith R, Severn Trent Water, personal communication, 2006).

Chemical phosphorus removal from sludge that is wasted from primary settlement or secondary treatment requires further treatment, the most common sludge stabilisation process being anaerobic digestion. When CPR sludge is fed into the low redox environment of an anaerobic digester, Fe(III) is reduced to $\mathrm{Fe}(\mathrm{II})$, in the process releasing phosphorus (Singer, 1972), as shown in equation (2). One investigator (Nielsen, 1996) noted that 'more than $90 \%$ of $\mathrm{Fe}(\mathrm{III})$ could be reduced to $\mathrm{Fe}(\mathrm{II})$ when stored anaerobically for several days'.

$\mathrm{Fe}_{\mathrm{r}} \mathrm{PO}_{4}(\mathrm{OH})_{3 \mathrm{r}-3 \times(\mathrm{s})}+\mathrm{e}_{\mathrm{r}}^{-} \leftrightarrow \mathrm{Fe}_{\mathrm{r}}^{2+}+\mathrm{PO}_{4}^{3-}+\mathrm{OH}_{3 \mathrm{r}-3}^{-}$
The briefly soluble $\mathrm{Fe}(\mathrm{II})$ and $\mathrm{PO}_{4}{ }^{3-}$-P would then be most likely to re-precipitate rapidly in digested sludge as ferrous phosphate.

\begin{tabular}{|l|l|}
\hline 3 & $3 \mathrm{Fe}^{2+}+2 \mathrm{PO}_{4}^{3-} \leftrightarrow \mathrm{Fe}_{3}\left(\mathrm{PO}_{4}\right)_{2(\mathrm{~s})}$ \\
\hline
\end{tabular}

Anaerobic digesters treating Fe(III)-rich CPR sludge will, therefore, undergo short periods of high soluble phosphate concentrations before mass re-precipitation reactions take place. As the inorganic balance of an anaerobic digester is usually regulated by sulfide and carbonate anions (Callander and Barford, 1983) it was hypothesised that this could cause widespread changes in metal speciation. Metals could be swept up during phosphate re-precipitation, becoming adsorbed and entrapped within the ferrous phosphate precipitates.

Alternatively, metals might undergo increasing solubility by being released from sulfide or carbonate precipitates due to $\mathrm{Fe}$ (II) competition for these anions. The bioavailability of inorganic nutrients required for anaerobic metabolism could be reduced, or the solubility of toxic metals could be increased, as a result of shifting inorganic profiles.

Little is currently known about how CPR processes change the distribution of iron, phosphorus and trace metals in activated and digested sludge. This research compared the inorganic profiles of AS and digested sludge from CPR STW with their undosed counterparts and discusses the potential implications of the observed changes.

The specific objectives were:

(a) to develop inorganic profiles for iron-dosed AS and for digesters treating iron-dosed CPR sludge, with respect to phosphorus, iron, calcium, magnesium and trace metals

(b) to assess the impact of iron dosing on metal and phosphorus bioavailability in activated and digested sludge.

\section{MATERIALS AND METHODS}

\section{I. Analytical methods for fractionation of metals and phosphorus in digested sludge}

Sequential chemical extractions are used to divide solid phase inorganic material into fractions by means of selective extractions using a sequence of reagents. The sequential chemical extraction methods used for metal and phosphorus fractionation are shown in Tables 1 and 2, respectively. Concentrations of metals and phosphorus extracted were measured using a sequential plasma emission spectrophotometer with an inductively coupled (argon) plasma source. All methods have previously been described in detail (Carliell-Marquet, 2001). Table 3 shows the tentative assignation of metal and phosphorus species to extracted fractions (Carliell-Marquet, 2001).

\subsection{Sludge sampling}

Generation of inorganic profiles for CPR sludge by sequential chemical extraction was done in three separate investigations:

(a) Comparison of activated sludge inorganic profiles from 12 full-scale STW (five iron-dosed; seven undosed).

(b) Iron-dosing a laboratory-scale activated sludge process to 


\begin{tabular}{|c|c|c|c|c|}
\hline $\begin{array}{l}\text { Metal species found in } \\
\text { these fractions }{ }^{\mathrm{a}}\end{array}$ & Reagent & Concentration & $\begin{array}{l}\text { Extraction } \\
\text { time }\end{array}$ & Liquid : solid ratio ( $\mathrm{ml}: \mathrm{g} \mathrm{DS}$ ) \\
\hline Exchangeable metals & $\mathrm{KNO}_{3}$ & I mol/l, (pH 6.5) & $15 \mathrm{~h}$ & $50: 1$ \\
\hline Adsorbed metals & $\mathrm{KF}$ & $0.5 \mathrm{~mol} / \mathrm{l},(\mathrm{pH} 6.5)$ & $15 \mathrm{~h}$ & $80: 1$ \\
\hline Organic-bound metals & $\mathrm{Na}_{4} \mathrm{P}_{2} \mathrm{O}_{7}$ & $0.1 \mathrm{~mol} / \mathrm{l},(\mathrm{pH} 9.95)$ & $\mathrm{I} 5 \mathrm{~h}$ & $80: 1$ \\
\hline Carbonate precipitates & EDTA & $0.1 \mathrm{~mol} / \mathrm{l},(\mathrm{pH} 4.63)$ & $15 \mathrm{~h}$ & $80: 1$ \\
\hline Sulfide precipitates & $\mathrm{HNO}_{3}$ & $1.0 \mathrm{~mol} / \mathrm{l},(\mathrm{pH} 0.25)$ & $15 \mathrm{~h}$ & $50: 1$ \\
\hline Residual metals & Acid digestion (boiling) & $4 \%$ & Approx. I h & $\begin{array}{l}\text { Sludge pellet }+1.3 \mathrm{ml} \text { conc. } \\
\mathrm{HNO}_{3}+2.7 \mathrm{ml} \text { conc. } \mathrm{HCl}\end{array}$ \\
\hline
\end{tabular}

${ }^{a}$ These categories were assigned in the original method (Stover et al., 1976); however, work done since using model compounds to assign metal species to metal fractions showed that metals of interest to this study do not always conform to these categories (Carliell-Marquet, 200I).

Table I. Successive stages of the metals sequential extraction method (method adapted from Stover et al., 1976).

\begin{tabular}{|c|c|c|c|c|}
\hline $\begin{array}{l}\text { Phosphorus species found } \\
\text { in these fractions }{ }^{\mathrm{b}}\end{array}$ & Reagent & Concentration & Time & Liquid : solid ratio ( $\mathrm{ml}$ : g DS) \\
\hline Labile P & Deionised water (deoxygenated) & $(\mathrm{pH} 6 \cdot 2)$ & $20 \mathrm{~min}$ & $30: 0 \cdot 5$ \\
\hline Struvite/ $\mathrm{CaCO}_{3}-\mathrm{P}$ & $\begin{array}{l}\text { Acetate buffer } \\
\text { Deionised water }\end{array}$ & $0.1 \mathrm{~mol} / \mathrm{l}(\mathrm{pH} \mathrm{5} \cdot 2)$ & $\begin{array}{r}45 \min \\
5 \mathrm{~min}\end{array}$ & $\begin{array}{l}30: 0 \cdot 5 \\
30: 0 \cdot 5\end{array}$ \\
\hline $\mathrm{CaCO}_{3}-\mathrm{P}$ & $\begin{array}{l}\text { Acetate buffer } \\
\text { Deionised water }\end{array}$ & $0.1 \mathrm{~mol} / \mathrm{l}(\mathrm{pH} 5 \cdot 2)$ & $\begin{array}{r}30 \min \\
5 \mathrm{~min}\end{array}$ & $\begin{array}{l}30: 0.5 \\
30: 0.5\end{array}$ \\
\hline \multirow[t]{2}{*}{$\begin{array}{l}\text { Fe P; Al P } \\
\text { Org P }\end{array}$} & $\begin{array}{l}\mathrm{NaOH} \text { SRPc } \\
\mathrm{NaOH}(\text { TP-SRP) }\end{array}$ & I mol/I (pH I3.76) & $18 \mathrm{~h}$ & $30: 0.5$ \\
\hline & Deionised water & & $5 \mathrm{~min}$ & $30: 0.5$ \\
\hline Ca-P & $\begin{array}{l}\mathrm{HCl} \\
\text { Deionised water }\end{array}$ & $0.5 \mathrm{~mol} / \mathrm{l}(\mathrm{pH} \mathrm{0.6)}$ & $\begin{array}{l}18 \mathrm{~h} \\
5 \mathrm{~min}\end{array}$ & $\begin{array}{l}30: 0.5 \\
30: 0.5\end{array}$ \\
\hline Residual P & Acid digestion (boiling) & & Approx. I h & $\begin{array}{l}\text { Sludge pellet }+1.3 \mathrm{ml} \text { conc. } \\
\mathrm{HNO}_{3}+2.7 \mathrm{ml} \text { conc. } \mathrm{HCl}\end{array}$ \\
\hline $\begin{array}{l}\text { b Phosphorus model compc } \\
\text { cThe NaOH extraction is } \\
\text { phosphorus. The difference }\end{array}$ & $\begin{array}{l}\text { unds were used to identify phospho } \\
\text { ivided into soluble reactive phospha } \\
\text { between total phosphorus (measure }\end{array}$ & $\begin{array}{l}\text { us species recovered t } \\
\text { e (SRP), which represe } \\
\text { by ICP) and SRP repr }\end{array}$ & $\begin{array}{l}\text { e fractions }(\mathrm{C} \\
\text { its iron- and al } \\
\text { esents the orga }\end{array}$ & $\begin{array}{l}\text { arliell-Marquet, } 200 \mathrm{I}) \\
\text { luminium-associated } \\
\text { anic phosphorus fraction. }\end{array}$ \\
\hline
\end{tabular}

\begin{tabular}{|c|c|c|}
\hline Metal species (tentative) & Fraction from metal extraction method (Table I) & Fraction from $\mathrm{P}$ extraction method (Table 2) \\
\hline $\begin{array}{l}\mathrm{FePO}_{4} \\
\mathrm{Fe}_{3}\left(\mathrm{PO}_{4}\right)_{2} \cdot 8 \mathrm{H}_{2} \mathrm{O} \\
\mathrm{Fe}(\mathrm{III}) \text {-hydroxy- } \mathrm{P} \\
\mathrm{FeCO} \\
\mathrm{FeS} \\
\mathrm{Ca}_{3}\left(\mathrm{PO}_{4}\right)_{2} \\
\mathrm{CaHPO}_{4} \\
\mathrm{CaCO}_{3}(+ \text { adsorbed } \mathrm{P}) \\
\mathrm{MgNH}_{4} \mathrm{PO}_{4} \cdot 6 \mathrm{H}_{2} \mathrm{O} \text { (struvite) }\end{array}$ & $\begin{array}{l}\mathrm{HNO}_{3}+\text { residual } \\
\text { EDTA + some } \mathrm{Na}_{4} \mathrm{P}_{2} \mathrm{O}_{7} \\
\text { EDTA + some } \mathrm{Na}_{4} \mathrm{P}_{2} \mathrm{O}_{7} \\
\text { EDTA } \\
\text { Residual + some } \mathrm{HNO}_{3} \\
\text { EDTA } \\
\mathrm{Na}_{4} \mathrm{P}_{2} \mathrm{O}_{7} \\
\mathrm{HNO}_{3}+\text { EDTA d } \\
\mathrm{Na}_{4} \mathrm{P}_{2} \mathrm{O}_{7}\end{array}$ & $\begin{array}{l}\mathrm{NaOH}(\mathrm{SRP}) \\
\mathrm{NaOH}(\mathrm{SRP}) \\
\mathrm{NaOH}(\mathrm{SRP}) \\
\text { Acetate (measure } \mathrm{Fe}) \\
\mathrm{HCl} \\
\mathrm{HCl} \\
\text { Acetate (measure } \mathrm{Ca} \text { ) } \\
\text { Acetate }\end{array}$ \\
\hline
\end{tabular}

${ }^{d}$ Recovery of $\mathrm{Ca}$ from $\mathrm{CaCO}_{3}$ (model compound) is in the residual fraction, however, experiments have suggested the formation of a more soluble $\mathrm{Ca}$-carbonate (possibly $\mathrm{Ca}-\mathrm{Mg}$-carbonate) in wastewater, that is extracted preferentially in EDTA.

Table 3. Assigning metal species (tentative) to extraction fractions

measure the effect of CPR on sludge characteristics under controlled laboratory conditions.

(c) Measuring full-scale digested sludge inorganic profiles during start-up of a CPR dosing programme.

\subsection{Sampling 12 STW to compare inorganic profiles of iron-dosed and undosed sludges}

Twelve STW were sampled; seven undosed and five iron-dosed (ferrous sulfate co-precipitation). The sampling programme has previously been described in more detail (Smith and Carliell-Marquet, 2008). Return activated sludge (RAS) was collected from all STW during a single $8 \mathrm{~h}$ period. Immediately after sampling, the sludge samples were stored in cool boxes and then placed in a refrigerator $\left(5 \pm 1^{\circ} \mathrm{C}\right)$ for overnight storage. Sequential chemical extraction was carried out in triplicate the following day.

\subsection{Simulation of CPR in a laboratory-scale activated sludge process}

A laboratory-scale activated sludge process was continuously dosed with ferrous chloride to remove phosphorus. The system has been described previously (Oikonimidis, 2007). Incoming 
feed to the plant consisted of synthetic wastewater (polysaccharides, proteins and volatile fatty acids; $\mathrm{COD} \approx 1000 \mathrm{mg} / \mathrm{l}$ ), which was balanced with appropriate concentrations of phosphorus, sulfur, nitrogen and bicarbonate. After a control period without chemical addition, ferrous chloride tetrahydrate $\left(\mathrm{FeCl}_{2} \cdot 4 \mathrm{H}_{2} \mathrm{O}\right)$ was dosed continuously into the aeration basin. Based on influent volume, the dose was $25 \mathrm{mg} / \mathrm{l}$ as iron.

\subsection{Sampling of digested sludge from a full-scale digester during onset of CPR}

The CPR at this STW was by pre-precipitation; ferric sulfate being dosed into raw sewage at a molar ratio of $2: 1$ (iron : phosphorus). Two anaerobic digesters (HRT $=22$ days; $35-36^{\circ} \mathrm{C}$ ) treated a mixture of iron-dosed primary sludge and humus sludge (75\% of the digester feed) plus some sludge imported into the STW for digestion (25\%). Samples of digested sludge were taken by way of a draw-off point at the top of the digester. These were delivered to the laboratory, refrigerated and sequentially extracted within $48 \mathrm{~h}$. Sampling of this digester was over a 118 day period at approximately 10 day intervals during start-up of iron dosing at the STW.

\section{RESULTS}

\section{I. Inorganic content of iron-dosed sludge}

Iron dosing of activated sludge increased the inorganic content of that sludge and proportionately decreased the volatile solids (VS) content of that sludge. This is shown in Figure 1, with data taken from a laboratory-scale AS continuously dosed with ferrous chloride over a 10 week period.

Figure 1 shows that the non-volatile suspended solids (nVSS) content of the mixed liquor suspended solids (MLSS) was less than 5\% before iron dosing, but following iron dosing the nVSS content rose steadily to reach $38 \%$ of the total MLSS solids. At the peak of iron dosing, nVSS comprised 18\% iron and $4 \%$ phosphorus, by weight. In the post-dosing period, ironrich sludge was slowly wasted from the reactor resulting in a corresponding decline in the nVSS content of the MLSS.

A similar increase in sludge nVSS content from CPR was found in the survey of 12 STW. The average nVSS content of irondosed AS was $35 \pm 4 \%(n=5)$, compared to $26 \pm 5 \%(n=7)$ for undosed sludge.

As the inorganic content of the AS increased, physical changes occurred. Figure 2 shows the floc structure during the first week of iron dosing (Figure $2 b$ and $d$ ) and at the peak of iron dosing (Figure 2a and c) in the laboratory AS plant. As a result of iron dosing, the flocs became more compact (Figure 2a) with a rusty brown coating. When viewed with scanning electron microscopy, the iron-dosed flocs show a smooth, uniform surface (Figure 2c) in comparison to undosed flocs (Figure 2d). Energy dispersive X-ray analysis spectra revealed that the iron content on the surface of heavily coated flocs (Figure 2c) was as high as $36 \pm 4 \%$, whereas for undosed flocs this was below $1 \%$.

\subsection{Iron fractionation profiles in CPR activated sludge}

Figure 3 shows the iron fractionation profiles of RAS sampled from five iron-dosed and seven undosed STW. Individual iron fractions are shown as a percentage of the total iron in the RAS (total iron concentration indicated above each profile). STW 8 had a relatively low total iron content for a CPR sludge ( $35 \mathrm{~g} / \mathrm{kg}$ ) but this represents a 10-fold increase in iron content of this sludge as a result of CPR, the pre-CPR iron RAS concentration being only $3 \mathrm{~g}$ iron/kg total solids (TS). STW 9 to 12 show typical iron-dosed profiles, with an average iron content of $107 \mathrm{~g}$ iron/ $\mathrm{kg}$ TS, in comparison to $13 \mathrm{~g}$ iron $/ \mathrm{kg}$ TS for the undosed STW.

To identify the characteristic profiles of undosed versus irondosed RAS, average iron fractionation profiles for undosed $(n=7)$ and iron-dosed sludges $(n=5)$ are shown in Figure 4. Soluble, potassium nitrate $\left(\mathrm{KNO}_{3}\right)$ and potassium fluoride (KF) fractions were combined into one fraction, as were the nitric acid and residual fractions. The first fraction in the series (soluble, potassium nitrate and potassium fluoride) represents iron that was readily extracted from the sludge and hence was likely to be biologically available. This fraction was lower in iron-dosed RAS: $0 \cdot 7 \%$ (0.65 g iron $/ \mathrm{kg}$ ) in comparison with $8 \%$ (0.87 $\mathrm{g}$ iron $/ \mathrm{kg})$ in undosed RAS. The sodium tetrapyrophosphate $\left(\mathrm{Na}_{4} \mathrm{P}_{2} \mathrm{O}_{7}\right)$ fraction was proportionately less in the iron-dosed RAS but actually represents $30.5 \mathrm{~g}$ iron $/ \mathrm{kg}$, in comparison with $6 \cdot 2 \mathrm{~g} / \mathrm{kg}$ in undosed sludge. This was the dominant iron fraction in undosed RAS and was likely to consist mainly of organically bound iron (Stover et al., 1976) and some Fe(III) hydroxide. In irondosed RAS, it is suggested that the sodium tetrapyrophosphate-extracted iron was solubilised mainly from amorphous, immature Fe(III)-hydroxy-phosphate compounds, with some contribution from $\mathrm{Fe}(\mathrm{III})$ hydroxide and organically bound iron. The CPR RAS was dominated by ethylene diamine tetra-acetic acid 

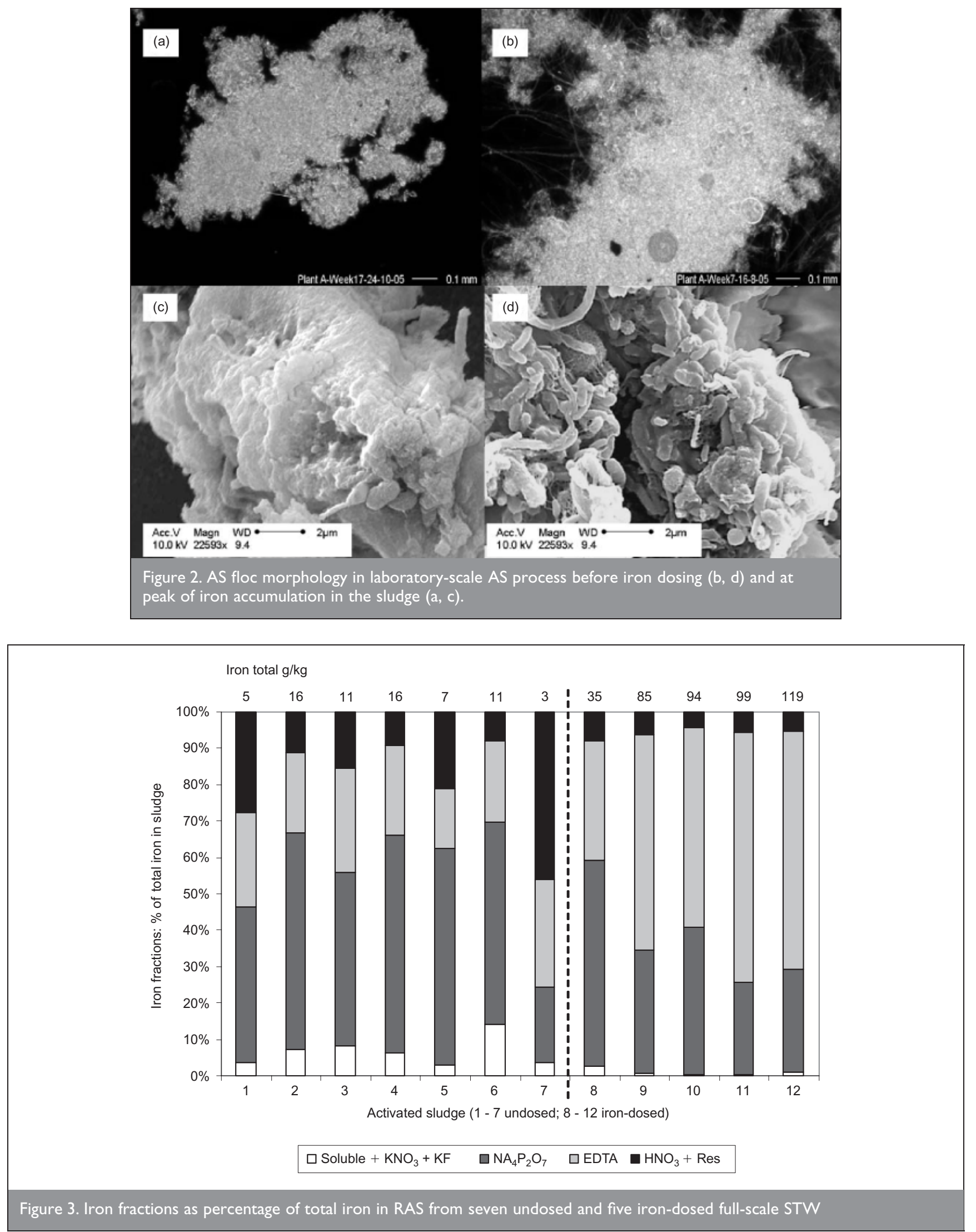

(EDTA)-extracted iron, which represents primarily mature (i.e. more resistant to extraction) Fe(III)-hydroxy-phosphate compounds.

\subsection{Phosphorus fractionation profiles in CPR activated sludge}

Figure 5 shows the average phosphorus fractionation profiles for undosed and iron-dosed RAS from the 12 STW. Soluble phosphorus, water-extracted phosphorus and acetate-extracted phosphorus were all designated as bioavailable phosphorus. The sodium hydroxide $(\mathrm{NaOH})$ fraction represents phosphorus extracted from iron phosphates (Fe(II) and Fe(II) phosphates and hydroxy-phosphates) and phosphorus extracted from organic sources. The hydrochloric acid plus residual phosphorus fraction represents phosphorus extracted from calcium phosphates. Figure 5 shows that iron-dosed RAS had 


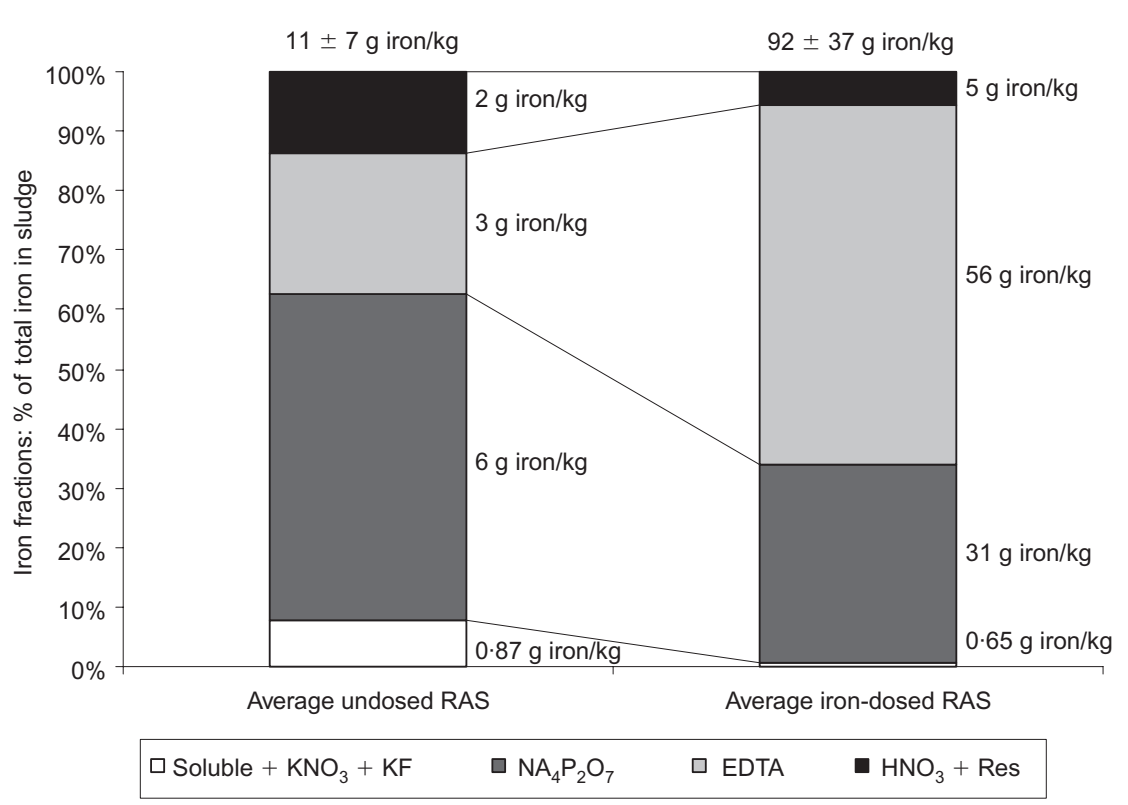

Figure 4. Average iron fractionation profiles of undosed RAS and iron-dosed RAS from full-scale STW

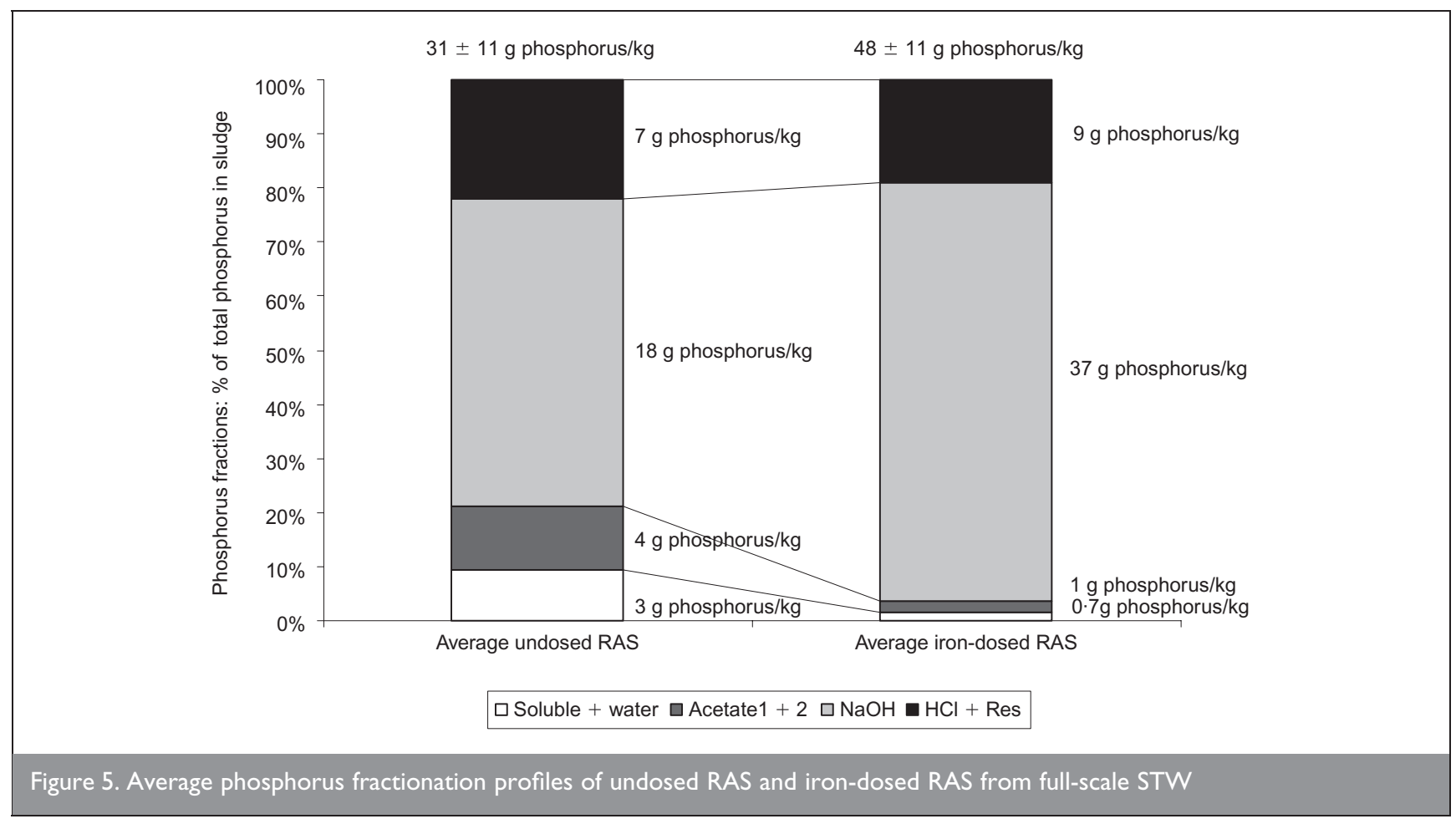

less bioavailable phosphorus than undosed RAS $(1.8 \mathrm{~g} / \mathrm{kg}$ in comparison with $6 \cdot 5 \mathrm{~g} / \mathrm{kg}$ ). Phosphorus fractionation in irondosed RAS was dominated by sodium hydroxide-extracted phosphorus. In the undosed RAS, sodium hydroxide-extracted phosphorus was derived mainly from organically bound phosphorus. The calcium phosphate fraction (hydrochloric acid + Res) was comparable for undosed and iron-dosed RAS.

\subsection{Calcium and magnesium fractionation profiles in CPR activated sludge}

In addition to iron and phosphorus fractionation profiles, profiles were generated for calcium and magnesium. No clear trends could be identified from the survey of 12 STW with respect to either calcium or magnesium fractionation profiles (results not shown) but a sample of RAS from STW 8 prior to and after 6 months of iron dosing showed an increase in soluble calcium concentrations after iron dosing $(1 \mathrm{mg} / \mathrm{l}$ to $3.77 \mathrm{mg} / \mathrm{l})$ and a slight decrease in nitric acid $\left(\mathrm{HNO}_{3}\right)$-extracted calcium, which is the fraction most closely associated with calcium phosphates.

\subsection{Inorganic fractionation profiles of digested sludge with CPR sludge input}

A full-scale anaerobic digester was sampled for 111 days during start-up of CPR at a STW. The digested sludge samples were sequentially extracted to identify phosphorus and metal 
fractions. Table 4 shows the digested sludge characteristics from pre-dosing until day 111 of CPR operation, indicating the changing conditions within the digester as a result of digesting CPR sludge. The first noticeable trend was that of increasing alkalinity, from $2685 \mathrm{mg} / \mathrm{l}$ prior to iron dosing to an average of $3651 \pm 57 \mathrm{mg} / \mathrm{l}$ for the last four samples.

As expected the TS of the digested sludge increased as a result of iron dosing of the feed sludge, from $1.94 \%$ to $2 \cdot 62 \pm 0 \cdot 2 \%$ (average of last four samples). The VS content of the digested sludge also increased during CPR sludge digestion; from $0 \cdot 82 \mathrm{~g} / 100 \mathrm{ml}$ to $1 \cdot 3 \pm 0.09 \mathrm{~g} / 100 \mathrm{ml}$. The VS also increased as a percentage of TS, being $42 \%$ pre-dosing and $50 \pm 1 \cdot 3 \%$ by day 111. This suggests that the digested sludge was not as efficiently stabilised as it was prior to CPR. Ammonia concentrations in the digester also increased from $322 \mathrm{mg} / \mathrm{l}$ to $515 \pm 17 \mathrm{mg} / \mathrm{l}$, probably as a result of increased organic loading to the digester. This might also be related to a higher protein content in the digester feed sludge resulting from increased protein coagulation through iron dosing the raw sewage.

\subsection{Iron fractionation profiles in digested sludge}

Figure 6 shows a steady accumulation of iron in the digested sludge from $18 \mathrm{~g} / \mathrm{kg}$ dried sludge pre-dosing to $72 \mathrm{~g} / \mathrm{kg}$ by day 111. The pre-dosing iron fractionation profile is dominated by sodium tetrapyrophosphate-extractable iron (35\%; 6.4 g/ kg), most likely derived from organic material in the sludge. The EDTA fraction constituted 32\% (5.8 g iron $/ \mathrm{kg}$ ), most likely representing a mixture of ferrous carbonate $\left(\mathrm{FeCO}_{3}\right)$ and ferrous phosphate $\mathrm{Fe}_{3}\left(\mathrm{PO}_{4}\right)_{2}$. The nitric acid plus residual fraction, in which ferrous sulfide (FeS) was solubilised, represented $29 \%$ of the total iron in the digested sludge, predosing.

As CPR sludge was fed to the digester, sodium tetrapyrophosphate $\left(\mathrm{Na}_{4} \mathrm{P}_{2} \mathrm{O}_{7}\right)$-extractable iron in the digested sludge increased from $6 \cdot 4 \mathrm{~g} / \mathrm{kg}$ to $26 \pm 1.7 \mathrm{~g} / \mathrm{kg}$ (average of last four samples). This represents an increase in organically bound iron resulting from iron coagulation of raw sewage, and partial recovery of iron from ferrous phosphate. EDTA-extracted iron (representing primarily ferrous phosphate) increased from $5 \cdot 8$ to $41 \cdot 3 \mathrm{~g} / \mathrm{kg}$ over the 111 days of CPR sludge digestion. Ferrous carbonate was also recovered in EDTA and to differentiate

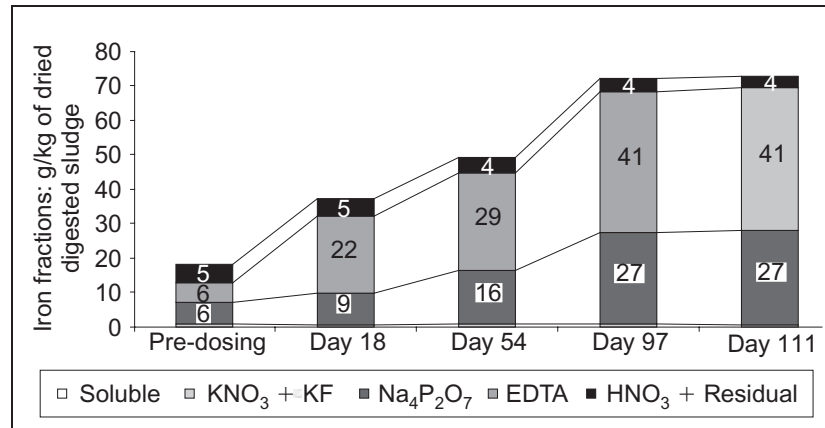

Figure 6. Iron fractions showing changing profile of a full-scale anaerobic digester pre- and post-CPR

between ferrous phosphate and carbonate, it is useful to measure iron in the acetate extractions of the phosphorus sequential extraction scheme, where ferrous carbonate was solubilised. This indicated that ferrous carbonate only increased from 1.26 to $3 \cdot 8 \mathrm{~g} / \mathrm{kg}$ by day 111 , confirming the dominance of ferrous phosphate in the EDTA fraction.

Most interesting is the reduction in nitric acid plus residual extracted iron (i.e. from ferrous sulfide) during CPR. Twentynine per cent of the iron pre-dosing was recovered in this fraction $(5.2 \mathrm{~g} / \mathrm{kg})$, which decreased to $3.6 \mathrm{~g} / \mathrm{kg}$ by day 111 , representing only $5 \%$ of the total iron in the digester. Iron is usually the primary regulator of sulfide solubility in an anaerobic digester, so a decrease in the formation of ferrous sulfide could result in higher concentrations of trace metals, such as nickel and cobalt, being precipitated as sulfides in the digested sludge.

These results suggest that iron solubility in the digester preCPR was controlled primarily by ferrous sulfide precipitation but that introduction of iron-dosed CPR sludge shifted the balance to ferrous phosphate precipitation, with ferrous sulfide decreasing in importance and ferrous carbonate increasing in importance.

\subsection{Phosphorus fractionation profiles in digested sludge}

Figure 7 shows the phosphorus profile of the anaerobic digester. Phosphorus in the digester increased in total as a result of CPR, with an average iron : phosphorus ratio in the digested sludge of

\begin{tabular}{|c|c|c|c|c|c|c|c|c|c|c|c|}
\hline & \multirow{2}{*}{$\begin{array}{l}\text { Pre iron } \\
\text { dosing }\end{array}$} & \multicolumn{10}{|c|}{ Dosing of primary sludge with ferric sulfate } \\
\hline & & Day II & Day 18 & Day 25 & Day 40 & Day 49 & Day 54 & Day 60 & Day 97 & Day 104 & Day III \\
\hline $\mathrm{pH}$ & 7.42 & 7.8 & 7.53 & $7 \cdot 52$ & $7 \cdot 35$ & 7.52 & $7 \cdot 25$ & 7.44 & 7.43 & 7.42 & 7.49 \\
\hline $\begin{array}{l}\text { Alkalinity: mg } \\
\mathrm{CaCO}_{3} / \mathrm{l}\end{array}$ & 2685 & 3237 & 3510 & 3394 & 3214 & 3127 & 3208 & 3063 & 3626 & 3679 & 3574 \\
\hline Sulfide: mg/l & $2 \cdot 2$ & 0.27 & $1 \cdot 2$ & $1 \cdot 3$ & $2 \cdot 6$ & 1.9 & 1.8 & $2 \cdot 3$ & 3.43 & 3.89 & $2 \cdot 1$ \\
\hline Ammonia: mg/l & 322 & 350 & 365 & 366 & 336 & 329 & 308 & no data & 507 & 522 & 534 \\
\hline $\mathrm{TOC}_{\text {soluble }}: \mathrm{mg} / \mathrm{l}$ & 969 & 926 & 1048 & $1|0|$ & 1101 & 1002 & $104 \mid$ & 1080 & $\mid 121$ & 1076 & 1043 \\
\hline$I_{\text {soluble }}: \mathrm{mg} / \mathrm{l}$ & 462 & 557 & 604 & 584 & 553 & 538 & 552 & 527 & 624 & 633 & 615 \\
\hline TS: g/l00 ml & 1.94 & 2.09 & $2 \cdot 47$ & $2 \cdot 37$ & $2 \cdot 46$ & $2 \cdot 16$ & $2 \cdot 25$ & $2 \cdot 14$ & $2 \cdot 33$ & 2.53 & $2 \cdot 84$ \\
\hline VS: g/l00 ml & 0.82 & 0.93 & 1.13 & 1.08 & 1.08 & 0.95 & 0.99 & 0.96 & $1 \cdot 2$ & 1.28 & $1.4 \mid$ \\
\hline$\% \mathrm{VS}$ & $42 \cdot 4$ & $44 \cdot 6$ & $45 \cdot 7$ & $45 \cdot 7$ & $43 \cdot 9$ & 44 & 44 & $44 \cdot 6$ & $51 \cdot 3$ & $50 \cdot 4$ & $49 \cdot 6$ \\
\hline
\end{tabular}




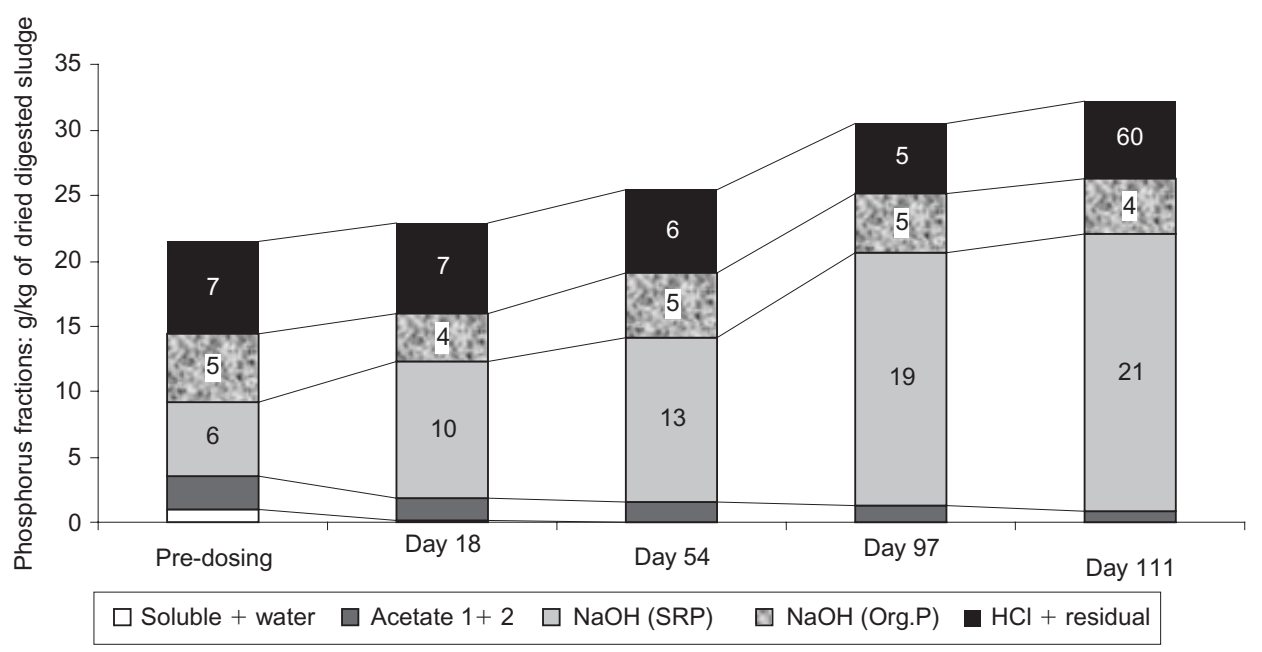

Figure 7. Phosphorus fractions showing changing profile of a full-scale anaerobic digester pre- and post-CPR

$2 \cdot 24 \pm 0 \cdot 3$ by day 111 . Digestion of the CPR sludge had an effect on every phosphorus fraction, with all fractions decreasing in both mass and percentage, except for the sodium hydroxide fraction. It should be noted that in Figure 7, the sodium hydroxide fraction has been further divided by differentiating between soluble reactive phosphorus (SRP) (representing phosphorus from inorganic iron phosphates) and non-reactive phosphorus (representing phosphorus from organic material). Sodium hydroxide-extracted SRP increased from 26\% (5.6 g/ $/ \mathrm{kg})$ pre-dosing to $64 \%(21 \mathrm{~g} / \mathrm{kg})$ by day 111 . By contrast, the hydrochloric acid plus residual $\mathrm{P}$ fraction (Ca-P), was reduced from $7 \cdot 2$ to $5 \cdot 9 \mathrm{~g} / \mathrm{kg}$.

Figure 8 shows the more labile phosphorus fractions in the digested sludge. These fractions were rapidly extracted with water and acetate buffer and so were considered to be biologically available. CPR sludge digestion had an immediate effect on the mass of bioavailable phosphorus in the digester, decreasing it from $3.61 \mathrm{~g} / \mathrm{kg}$ pre-dosing to $1.65 \mathrm{~g} / \mathrm{kg}$ by day 111. Moreover, the remaining bioavailable phosphorus is almost entirely represented by the acetate-extractable phosphorus, with the soluble and water phosphorus fractions having decreased by $96 \%$ from their pre-dosing levels. The COD : $\mathrm{P}_{\text {bioavailable }}$ ratio in the digester sludge was $170: 1$ predosing but increased to $840: 1$ by day 111 .

\subsection{Fractionation profiles of other metals in digested sludge}

As well and iron and phosphorus, which are directly involved in the CPR process, other metals were fractionated to identify changes in their profiles. The first noticeable change in the digested sludge was that all metals measured, apart from iron, decreased in terms of their mass per mass of dried sludge over the 111 day period. On average, metals decreased by $39 \pm 3 \%$

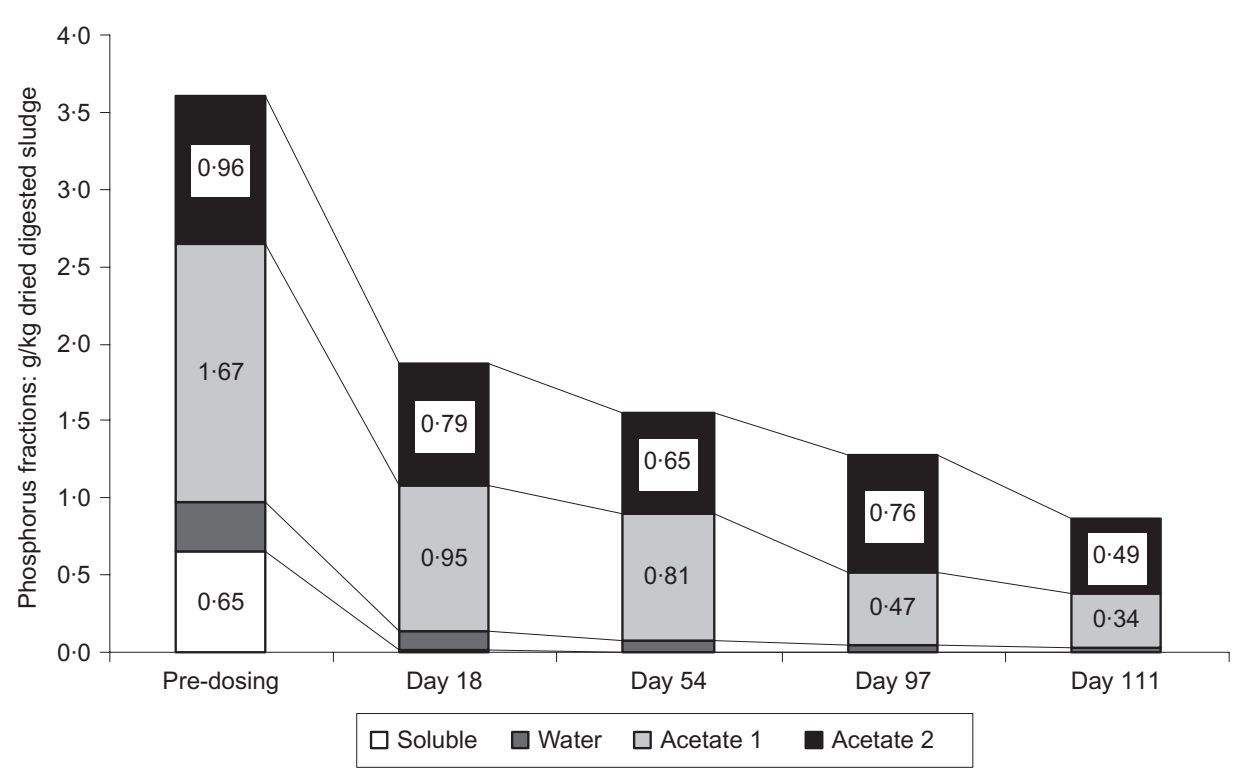

Figure 8. Bioavailable phosphorus fractions in a full-scale anaerobic digester pre- and post-CPR 
from their pre-dosing levels, with the biggest decrease being by calcium (43\%) and the smallest by manganese (34\%). This is thought to be related primarily to the increase in total solids concentration in the feed and digested sludge (Table 4), as a result of CPR, with non-dosed metals being proportionately less on a weight-for-weight basis.

Calcium is usually an important precipitant of phosphorus in digesters, but the hydrochloric acid-extracted phosphorus (Figure 7) suggested Ca-P had decreased as a result of CPR sludge digestion. This was supported by the calcium extraction profiles, which showed decreasing extraction of calcium from the Ca-P fractions, with a corresponding increase in soluble calcium in the digester (Figure 9).
Magnesium (results not shown) followed a similar trend to calcium, although changes were slower and less pronounced. Soluble magnesium was stable for the first 96 days of CPR at $40 \pm 2.5 \mathrm{mg} / \mathrm{l}$ but then increased to $52 \mathrm{mg} / \mathrm{l}$ by day 111 . As for calcium, fractions of magnesium at the upper end of the fractionation profile (residual magnesium, nitric acid and EDTA extractable magnesium), which are likely to represent magnesium phosphate precipitates, decreased.

Trace metals (nickel, copper, zinc, chromium, manganese) were also fractionated using the metals sequential extraction method, the results are presented in Figure 10. Two fractionation profiles are shown for each metal: pre-dosing and day 60 of CPR. With the exception of manganese, all the trace
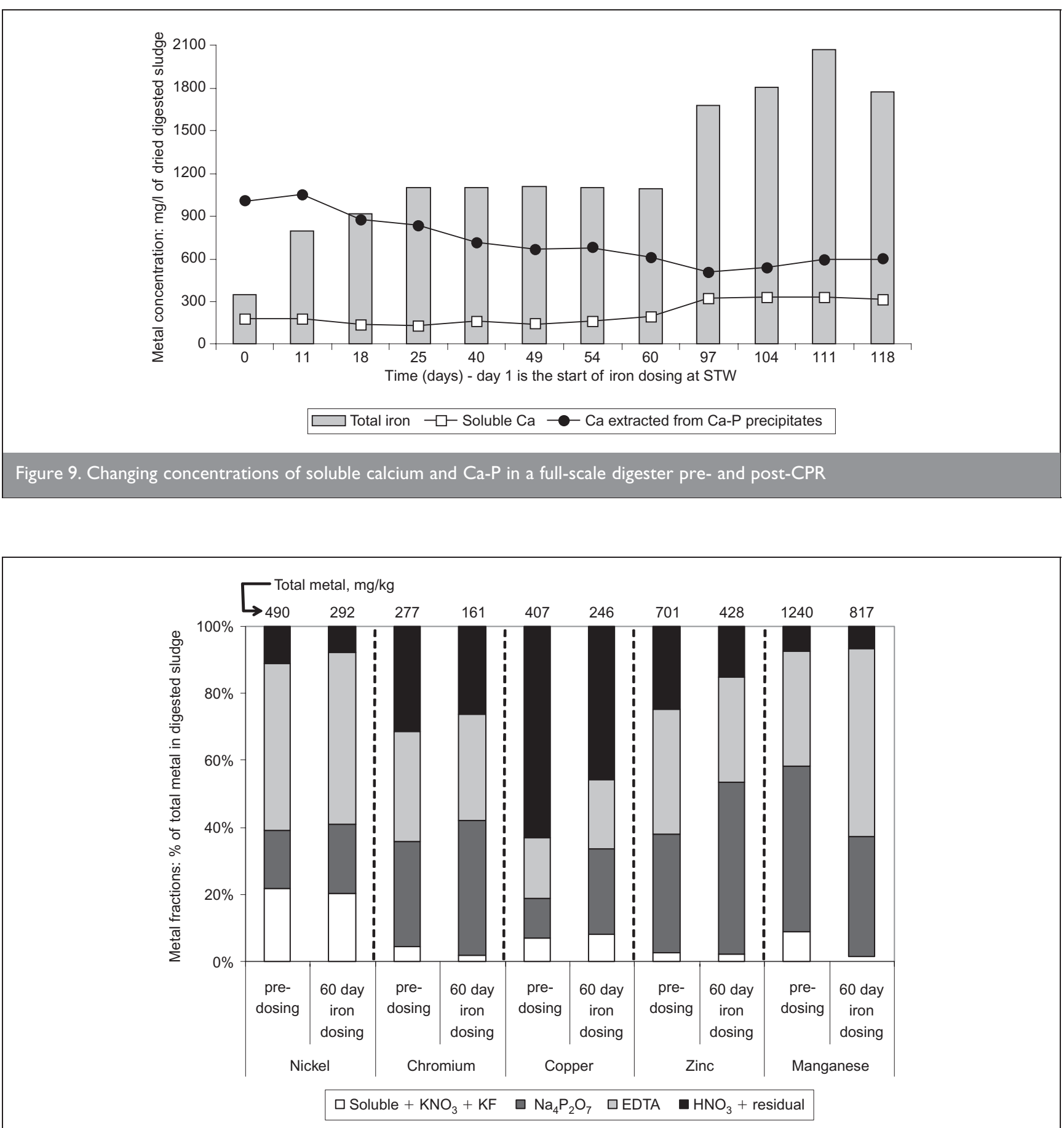

Figure 10. Trace metal fractionation profiles in a full-scale anaerobic digester pre- and post-CPR 
metals exhibited a shift towards the lower end of the fractionation profiles, suggesting they could be more easily extracted from the sludge post-CPR. Copper is particularly interesting: pre-dosing copper was resistant to extraction, with 63\% in the nitric acid and residual fractions, indicating that most copper was present as copper sulphide. Following CPR, copper in the digested sludge shifts towards the sodium tetrapyrophospate $\left(\mathrm{Na}_{4} \mathrm{P}_{2} \mathrm{O}_{7}\right)$ and EDTA fractions. CPR sludge digestion has the opposite effect on manganese fractionation, with manganese becoming less extractable over the 60 day period, shifting up the fractionation profile to be extracted primarily with EDTA.

\section{DISCUSSION}

Chemical phosphorus removal has been found to induce changes in metal and phosphorus fractionation in wastewater sludge, with the bioavailability of a number of metals and phosphorus being affected.

The bioavailability of a metal can be defined as the fraction of the total metal in a particular environment that is in a form suitable for uptake by a cell (Turner, 1984). The size of this fraction is important in determining the availability of essential trace nutrients or toxicity of metals. It is difficult to measure and there is little evidence to relate metal speciation and metal bioavailability in wastewater treatment systems (Zandvoort et al., 2006). Sequential chemical extractions give an insight into metal dynamics in wastewater sludges. The chemical extractants are applied in order of increasing aggressivity to divide the metals into fractions that represent their ease of extraction; the most readily extractable being at the beginning of the sequence and the most resistant, for example, the sulfide precipitates, towards the end. Hence, it can be assumed that biological availability of the metal fractions is greatest in the initial fractions and the metals (or phosphorus) become increasingly unavailable as the fractions progress through the sequence (Aquino and Stuckey, 2007; Carliell-Marquet, 2001; Zandvoort et al., 2006).

Soluble metals are considered to be the most readily bioavailable fraction, but most soluble metals in wastewater treatment systems are not free ions in solution; they are complexed with a range of soluble organic ligands and inorganic ions. These metals are, therefore, only bioavailable if the wastewater micro-organisms have a stronger affinity for the metal than the complexing agent (Callander and Barford, 1983). Previous researchers have concluded that precipitated metals are not readily bioavailable to micro-organisms (Aquino and Stuckey, 2007; Callander and Barford, 1983; Gonzalez-Gil et al., 2002; Hoban and van den Berg, 1979; Mosey et al., 1971; Pfeffer and White, 1964; Zandvoort et al., 2006), which corresponds to their resistance to extraction.

It is important to note, however, that metal distribution between soluble and solid phases is a dynamic phenomenon, which changes continually depending on the concentration of each metal in a particular environment and competition between them for adsorption and complexation sites and precipitating anions. Thus precipitated metals are not readily bioavailable but represent a reservoir of metal that could become bioavailable if environmental conditions change (Ginter and Grobicki, 1997; Gonzalez-Gil et al., 2002).
Speciation of metals governs metal toxicity in a similar manner to that of bioavailability, with metal species unavailable to micro-organisms also being rendered less toxic to microorganisms (Hughes and Poole, 1989; Mehrota et al., 1993; Mosey et al., 1971).

For the metals sequential extraction method (Table 1), bioavailable fractions were designated as the soluble fraction and the fractions containing readily exchangeable metal (potassium nitrate) and adsorbed metal (potassium fluoride). As metal uptake by microbial cells is thought to start with passive adsorption of metal onto the cell surface (Turner, 1984), this seems a good indication of metal bioavailability. The second phase of metal uptake is energy-dependent transport into the cell (Hughes and Poole, 1989), hence the organically bound metal fraction sodium tetrapyrophosphate $\left(\mathrm{Na}_{4} \mathrm{P}_{2} \mathrm{O}_{7}\right)$ could also be representative of metal bioavailability. However, a number of inorganic precipitates also contribute to this fraction by being partially solubilised in sodium tetrapyrophosphate $\left(\mathrm{Na}_{4} \mathrm{P}_{2} \mathrm{O}_{7}\right)$; for this reason the sodium tetrapyrophosphate $\left(\mathrm{Na}_{4} \mathrm{P}_{2} \mathrm{O}_{7}\right)$ fraction has not been included with the bioavailable fractions.

For the phosphorus sequential extraction method (Table 2), bioavailable fractions were designated as the soluble, waterand acetate-extractable fractions. The acetate-extractable fractions do contain phosphorus adsorbed to calcium carbonate or within struvite, but are included because this is a relatively mild extraction for a short time period and hence represents phosphorus from precipitates that are rapidly solubilised under weakly acidic conditions.

The inorganic profiles presented in this study show a general trend of decreasing bioavailability of iron and phosphorus in iron-dosed sludge. Iron bioavailability decreases in both irondosed AS and digested sludge. This is a relatively small decrease (870-650 mg/kg in AS and 640-590 mg/kg in digested sludge) but then the initial amount of bioavailable iron was only a small fraction of the total iron, so it is possible that a relatively small change could tip the balance towards that system being iron deficient. Iron is known to be an essential metal for all micro-organisms (Hughes and Poole, 1989) and has been reported to increase AS microbial activity when supplemented to nutrient-deficient systems (Carter and McKinney, 1973; Derco et al., 1998). Iron is particularly important for efficient anaerobic metabolism (Callander and Barford, 1983; Hoban and van den Berg, 1979; Pfeffer and White, 1964) and has been found to increase biogas production significantly when supplemented to anaerobic digesters with low bioavailable iron concentrations.

Decreasing bioavailable phosphorus (Figures 5, 7 and 8) is an obvious outcome of CPR, when the intention is to precipitate phosphorus. A marked reduction in the amount of soluble and water-extractable phosphorus was found in iron-dosed AS $(2 \cdot 9-0 \cdot 7 \mathrm{~g} / \mathrm{kg})$ as well as acetate-extractable phosphorus. Aerobic treatment systems have well established COD : nitrogen : phosphorus requirements $(100: 5: 1)$ and it is possible that iron dosing could reduce bioavailable phosphorus below this level.

Reduction of bioavailable phosphorus was even more extreme 
in the anaerobic digester (Figure 8), resulting in no measurable soluble phosphorus and very little water- or acetate-extractable phosphorus (2.63-0.83 g/kg); decreasing phosphorus bioavailability being clearly linked to the input of iron-dosed primary sludge to the digester. Anaerobic digesters, like all biological systems, are known to require phosphorus although exactly how much has not been established. A COD : phosphorus ratio of $125: 1$ has previously been recommended for anaerobic sludge digesters (Jack et al., 1976).

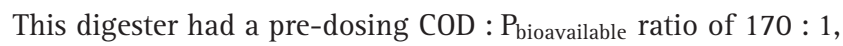
which increased to $840: 1$ post-CPR. It seems likely that, if these conditions were sustained, this digester would become phosphorus deficient, which could lead to slower rates of acetate utilisation and a reduction in methane output (Alphenaar et al., 1993). This needs to be taken into account when developing a CPR dosing programme for a STW, as optimising the iron dose might not only be an important factor in reducing chemical costs for CPR but might also be critical in ensuring a minimum level of bioavailable phosphorus in the digesters, which is in turn important to ensure steady biogas production.

Chemical phosphorus removal sludge digestion actually increased the bioavailability of metals such as calcium, magnesium, copper and zinc. Calcium solubility in digested sludge increased when iron-dosed primary sludge was fed to the digester, as a result of decreased calcium phosphate precipitation. Calculating the free $\mathrm{Ca}^{2+}$ concentration in equilibrium with orthophosphate $\left(\mathrm{PO}_{4}{ }^{3-}\right)$ or carbonate $\left(\mathrm{CO}_{3}{ }^{2-}\right)$ ( $K_{\mathrm{sp}}=10^{-6 \cdot 7}$ for calcium carbonate in wastewater (Loewenthal, 1997) showed that calcium solubility in the digester was controlled by phosphate precipitation prior to iron dosing. Post-CPR sludge digestion, with soluble phosphorus less than $0.05 \mathrm{mg} / \mathrm{l}$, calcium solubility was controlled primarily by carbonate precipitation, thus increasing soluble calcium concentrations. A consequence of increased calcium and magnesium solubility in wastewater is likely to be a greater incidence of pipework scaling by calcium carbonate or calcium magnesium carbonate $\left(\mathrm{Ca}-\mathrm{Mg}-\mathrm{CO}_{3}\right)$ precipitates, particularly if the trend towards increasing alkalinity in the digester is also taken into account. This likelihood is further exacerbated by the lack of soluble orthophosphate in the wastewater, which acts as an inhibitor for calcium precipitation.

Both copper and zinc in digested sludge (Figure 10) moved down the fractionation profiles after CPR sludge digestion, although this did not alter the designated bioavailable fractions. It seems that copper in particular was less strongly precipitated with sulfide than before CPR. Both metals showed an increase in the sodium tetrapyrophosphate $\left(\mathrm{Na}_{4} \mathrm{P}_{2} \mathrm{O}_{7}\right)$ fraction, which could represent increasing concentrations of copper and zinc in microbial cells. In previous work, increasing sodium tetrapyrophosphate-extracted copper was found to be indicative of digester deactivation (Hayes and Theis, 1978; Mehrota et al., 1993), due to copper build-up in the biomass fraction. Thus, CPR sludge digestion could mobilise metals such as copper and zinc that are traditionally strongly precipitated as sulfides. The reason for this is unclear; intuitively it would seem that increasing iron concentrations in the digester could limit sulfide availability for precipitation with trace metals; however, iron fractionation profiles suggested lower ferrous sulfide concentrations in the digester post-CPR and soluble sulfide measurements also increased post-CPR. It is also possible that copper and zinc were caught up in the ferrous phosphate re-precipitation reactions, becoming adsorbed to or entrapped within the precipitates and then being released in the sodium tetrapyrophosphate $\left(\mathrm{Na}_{4} \mathrm{P}_{2} \mathrm{O}_{7}\right)$ fraction. This certainly occurred with manganese, which was extensively coprecipitated with ferrous phosphate and recovered in the EDTA fraction. Manganese is an essential trace metal, particularly important for the acidogenic bacteria in anaerobic digestion (Hughes and Poole, 1989). Thus reducing manganese bioavailability could have a negative effect on anaerobic digestion and consequently, biogas production.

\section{CONCLUSIONS AND RECOMMENDATIONS}

(a) Iron dosing for CPR alters the solubility and bioavailability of iron, phosphorus and trace metals in activated and digested sludge.

(b) Iron-dosed AS contained on average eight times the mass of iron and 1.5 times the mass of phosphorus found in undosed AS. Iron and phosphorus are most likely bound up as Fe(III)-hydroxy-phosphate and are unlikely to be biologically available.

(c) The bioavailable phosphorus fraction in iron-dosed AS was on average only $28 \%$ of that found in undosed AS. This implies that iron dosing could cause phosphorus limitation in AS under conditions of high dosing. More work is needed to understand the relationship between the nutrient requirements of AS and nutrient bioavailability.

(d) CPR sludge fed to anaerobic digesters will result in phosphorus being re-precipitated as ferrous phosphate within the digested sludge. This is likely to reduce phosphorus bioavailability in the digesters. In this study it was reduced to $30 \%$ of pre-dosing levels. Hence, phosphorus bioavailability could become a limiting factor for digesters treating high proportions of iron-dosed sludge and further work is needed to establish the conditions under which this might occur.

(e) Anaerobic digestion of CPR sludge resulted in other metals (calcium, magnesium, copper, chromium, zinc, nickel) being more easily extracted post-dosing, except for manganese which was more resistant to extraction. For calcium this was related to reduced precipitation of calcium phosphates and for the trace metals this was thought to be caused by the metals being caught up in the ferrous phosphate re-precipitation reactions, instead of being precipitated as metal sulfides or carbonates. This is likely to increase the biological uptake of these trace metals, which could be beneficial or inhibitory depending on the metal and the concentrations involved. More work is needed to further our understanding of metal bioavailability in anaerobic digesters.

\section{ACKNOWLEDGEMENTS}

Results used in this paper are from research funded by EPSRC grants GR/K/96946 and GR/R58550/01; and PGTA funding (Department of Civil Engineering, The University of Birmingham).

\section{REFERENCES}

Alphenaar PA, Sleyster R, De Reuver P, Ligthart GJ and Lettinga G (1993) Phosphorus requirement in high-rate 
anaerobic wastewater treatment. Water Research 27(5): $749-$ 756.

Aquino SF and Stuckey DC (2007) Bioavailability and toxicity of metal nutrients during anaerobic digestion. Journal of Environmental Engineering - ASCE 133(1): 28-35.

Brett S, Guy J, Morse GK and Lester JN (1997) Phosphorus Removal and Recovery Technologies. Selper Publications, London, UK

Callander IJ and Barford JP (1983) Precipitation, chelation and the availability of metals as nutrients in anaerobic digestion. I. Methodology. Biotechnology and Bioengineering 15(8): 1947 - 1957.

Carliell-Marquet CM (2001) The Effect of Phosphorus Enrichment on Fractionation of Metal and Phosphorus in Anaerobically Digested Sludge. PhD Thesis, Loughborough University.

Carter JL and McKinney RE (1973) Effects of iron on activated sludge treatment. Journal of Environmental Engineering ASCE 99(EE2): 135-152.

De Haas D, Wentzel M and Ekama G (2000) The use of simultaneous chemical precipitation in modified activated sludge systems exhibiting biological excess phosphate removal. Part 1: Literature review. Water SA 26(4): 439451.

Derco J, Kuffa R, Kusnierova J and Fargasova A (1998) Influence of phosphorus precipitants on activated sludge activity. Journal of Trace and Microprobe Techniques 16(4): 417-425.

Edwards M, Courtney B and Heppler PS (1997) Beneficial discharge of iron coagulation sludge to sewers. Journal of Environmental Engineering - ASCE 123(10): 10271032.

Fytianos K, Voudrias E and Raikos N (1998) Modelling of phosphorus removal from aqueous and wastewater samples using ferric iron. Environmental Pollution 101(1): 123-130.

Ginter MO and Grobicki AM (1997) Manganese removal mechanisms in a stirred UASB reactor. Water Research 31(6): 1261 - 1268.

Gonzalez-Gil G, Jansen S, Zandvoort MH and van Leeuwen HP (2002) Effect of yeast extract on speciation and bioavailability of nickel and cobalt in anaerobic digesters. Biotechnology and Bioengineering 82(2): 134-142.

Hayes TD and Theis TL (1978) The distribution of heavy metals in anaerobic digestion. Journal of the Water Pollution Control Federation 50(1): 61-72.

He Q, Leppard G, Paige C and Snodgrass W (1996) Transmission electron microscopy of a phosphate effect on the colloid structure of iron hydroxide. Water Research 30(6): $1345-1352$.

Hoban DJ and van den Berg L (1979) Effect of iron on conversion of acetic acid to methane during methanogenic fermentation. Journal of Applied Bacteriology 47(1): 153159.

Hughes MN and Poole RK (1989) Metals and Microorganisms. Chapman and Hall, London.

Jack ME, Farquhar GJ and Cornwall GM (1976) Anaerobic digestion of primary sludge containing iron phosphate.

Water Pollution Research in Canada 8: 91-109.

Jenkins D, Ferguson JF and Menar AB (1971) Chemical processes for phosphate removal. Water Research 5(7): 369 387.

Jiang J and Graham N (1998) Pre-polymerised inorganic coagulants and phosphorus removal by coagulation - a review. Water SA 24(3): 237-244.

Kindzierski W and Hrudey S (1986) Effects of phosphorus removal chemicals upon methane production during anaerobic sludge digestion. Canadian Journal of Civil Engineering 31(1): 33-38.

Kirk PW, Hunter M, Lester JN and Perry R (1987) Chemically assisted phosphorus precipitation: effects on anaerobic digestion and AERCON sludge thickening. Environmental Technology Letters 8(11): 545-554.

Loewenthal RE (1997) The Application of Chemical Equilibrium to the Control of Struvite and Calcite Precipitation in Waste Water Treatment. Water Research Commission (South Africa) Report No. 602/1/97.

Mainstone C, Parr W and Day M (2000) Phosphorus and River Ecology - Tackling Sewage Inputs. English Nature/ Environment Agency Report, March 2000, UK.

Malhrota SK and Parrillo TP (1971) Anaerobic digestion of sludges containing iron phosphates. Journal of the Sanitary Engineering Division, Proceedings of the American Society of Civil Engineers, 97(5): 629-645.

Mehrota A, Mehrota I and Tandon SN (1993) Role of Cu (II) and $\mathrm{Zn}$ (II) species on the anaerobic digestion of synthetic activated sludge. Journal of Chemical Technology and Biotechnology 56(2): 185-190.

Mosey FE, Swanwick JD and Hughes DA (1971) Factors affecting the availability of heavy metals to inhibit anaerobic digestion. Water Pollution Control 70(6): 668-679.

Mounsey S (2004) Public considerations for sustainable phosphorus removal. Proceedings of CIWEM Conference Phosphorus Removal from Wastewaters: Still a Problem in the UK. Leeds, CIWEM, UK.

Nielsen PH (1996) The significance of microbial Fe(III) reduction in the activated sludge process. Water Science and Technology 37(4-5): 403-406.

Oikonimidis I (2007) Iron Accumulation in Activated Sludge as a Result of Chemical Phosphorus Removal - Effect on Floc Properties and Biological Activity. $\mathrm{PhD}$ thesis, The University of Birmingham.

Pfeffer JT and White JE (1964) The role of iron in anaerobic digestion. Proceedings of 19th Industrial Waste Conference, Purdue University Press, USA. pp. 887-901.

Singer PC (1972) Anaerobic control of phosphate by ferrous iron. Journal of the Water Pollution Control Federation 44(4): $663-669$.

Smith JA and Carliell-Marquet CM (2008) The digestibility of iron-dosed sludge. Bioresource Technology 99(18): 85858592.

Stover RC, Sommers LE and Silveira DJ (1976) Evaluation of metals in wastewater sludge. Journal of the Water Pollution Control Federation 48(9): 2165-2175.

Straub K, Benz M and Schink B (2001) Iron metabolism in anoxic environments at near neutral pH. FEMS Microbiology Ecology 34(3): 181-186.

Thistleton J, Clark T, Pearce P and Parsons S (2001) Mechanisms of chemical phosphorus removal 1 - Iron (II) salts. Transactions of the Institution of Chemical Engineers 79(B): $339-344$.

Thistleton J, Berry TA, Pearce P and Parsons S (2002) Mechanisms of chemical phosphorus removal 2 - Iron (III) salts. Transactions of the Institution of Chemical Engineers 80(B): 265-269. 
Turner DR (1984) Relationships between biological availability and chemical measurements. In Metal Ions in Biological Systems, Vol. 18: Circulation of Metals in the Environment (Sigel H (ed.)). Marcel Dekker, New York, pp. 137-164.

Uhlmann D, Roske I, Hupfer M and Ohms G (1990) A simple method to distinguish between polyphosphate and other phosphate fractions of activated sludge. Water Research 24(11): 1355-1360.

van Fleet G, Barr J and Harris A (1974) Treatment and disposal of chemical phosphate sludge in Ontario. Journal of the Water Pollution Control Federation 46(3): 582-587.

Yeoman S, Stephenson T, Lester JN and Perry R (1988) The removal of phosphorus during wastewater treatment: a review. Environmental Pollution 49(3): 183-233.

Zandvoort MH, Van Hullebusch ED, Fermoso FG and Lens PN (2006) Trace metals in anaerobic granular sludge reactors: bioavailability and dosing strategies. Engineering Life Science 6(3): 293-301.

\section{What do you think?}

To discuss this paper, please email up to 500 words to the editor at journals@ice.org.uk. Your contribution will be forwarded to the author(s) for a reply and, if considered appropriate by the editorial panel, will be published as discussion in a future issue of the journal.

Proceedings journals rely entirely on contributions sent in by civil engineering professionals, academics and students. Papers should be 2000-5000 words long (briefing papers should be 1000-2000 words long), with adequate illustrations and references. You can submit your paper online via www.icevirtuallibrary.com/content/journals, where you will also find detailed author guidelines. 